\title{
The effect of single dose etomidate during emergency intubation on hemodynamics and adrenal cortex
}

\author{
Güniz Meyancı Köksal, M.D., ${ }^{1}$ Emre Erbabacan, M.D., ${ }^{1}$ Yusuf Tunalı, M.D., ${ }^{1}$ \\ Gülşah Karaören, M.D., ${ }^{1}$ Suphi Vehid, M.D., ${ }^{2}$ Huseyin Öz, M.D. ${ }^{1}$ \\ ${ }^{1}$ Department of Anesthesiology and Reanimation, Istanbul University Cerrahpasa Faculty of Medicine, Istanbul \\ ${ }^{2}$ Department of Biostatistics, Istanbul University Cerrahpasa Faculty of Medicine, Istanbul
}

\begin{abstract}
BACKGROUND: The study aimed to evaluate and compare the effects of a single dose of etomidate and the use of a steroid injection prior to etomidate during rapid sequence intubation on hemodynamics and cortisol levels.

METHODS: Sixty patients were divided into three groups $(n=20)$. Before intubation, and at 4 and 24 hours, blood samples were taken for cortisol measurements and hemodynamic parameters (systolic-diastolic-mean arterial pressure, heart rate), and SOFA scores were recorded. Intubation was achieved with $0.3 \mathrm{mg} / \mathrm{kg}$ etomidate IV in Group I, $0.3 \mathrm{mg} / \mathrm{kg}$ etomidate following $2 \mathrm{mg} / \mathrm{kg}$ methylprednisolone IV in Group II, and $0.15 \mathrm{mg} / \mathrm{kg}$ IV midazolam in Group III.
\end{abstract}

RESULTS: Mean arterial pressure values were lower in Group I at the $24^{\text {th }}$ hour when compared to Groups II and III. In Group I, heart rate values were higher compared to the other Groups. Cortisol levels were lower in Group I at the $4^{\text {th }}$ and at the $24^{\text {th }}$ hour in Groups II and III.

CONCLUSION: Administration of methylprednisolone 2-4 minutes prior to etomidate use in emergency situations can prevent adrenal insufficiency in patients undergoing rapid sequence intubation. Moreover, midazolam can be used in low induction doses as an alternative to etomidate.

Keywords: Adrenal insufficiency; etomidate; midazolam; rapid sequence intubation.

\section{INTRODUCTION}

Endotracheal intubation is a common procedure performed in emergency departments. Emergency patients who require intubation also need an induction agent for rapid-sequence intubation (RSI). ${ }^{[1]}$ Administration of etomidate is still controversial in RSI. Multiple studies evaluating a single induction dose of etomidate and its effect on adrenal dysfunction and mortality have reported that even a single dose of etomidate can create adrenal dysfunction. ${ }^{[1-6]}$

A period is needed to diagnose patients who arrive at hospi-

Address for correspondence: Güniz Meyancı Köksal, M.D. İstanbul Üniversitesi Cerrahpaşa Tıp Fakültesi, Anesteziyoloji ve Reanimasyon Anabilim Dalı Sekreterliği, Fatih, İstanbul, Turkey Tel: +90 212 - 41430 00/22874 E-mail: gunizkoksal@hotmail.com

Qucik Response Code Ulus Travma Acil Cerrahi Derg

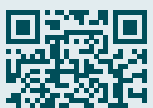
口iknis: 20I5;2I(5):358-365 doi: $10.5505 /$ tjtes.2015.06325

Copyright 2015 TJTES tals in emergency situations. Primary interventions are fully clinical symptom oriented since it is uncertain if patients will get a sepsis diagnosis. It is essential to remember that, even if patients receiving emergency services lack a sepsis diagnosis, many conditions such as hypovolemia, malnutrition, acute attack of chronic diseases, and acute kidney failure can cause "systemic inflammatory response syndrome" (SIRS). Patients with a SIRS diagnosis have a higher probability of subsequently receiving a sepsis or severe sepsis diagnosis. Thus, limitation or even prevention of etomidate use during emergency conditions should be reconsidered. We believe that in order to use the advantages etomidate offers, we must develop different usage strategies, or work on alternative induction agents. Midazolam and etomidate are two of the most common agents used during rapid sequence intubation. ${ }^{[7,8]}$ Etomidate has been favored over other induction agents like midazolam by many physicians during RSI, mainly because of its hemodynamic tolerance in unstable patients. ${ }^{[7]}$ Midazolam has no depressant impact over the adrenal cortex and, in addition, has anti-inflammatory and anti-convulsive action. However, midazolam can cause hypotension. It also has a broad doseresponse relationship that makes dosing inconsistent. ${ }^{[2]}$ In contrast, etomidate is used in inductions during RSI since it 
allows for a rapid, smooth and hemodynamically stable intubation. ${ }^{[1,2]}$

The primary outcome of this study was to evaluate the effect of using steroid on the adrenal cortex prior to a single dose of etomidate. Our secondary outcome measure was to compare the effects of midazolam and etomidate on hemodynamics.

The study aimed to evaluate the effects of a single dose of etomidate and the use of methylprednisolone prior to etomidate during RSI on hemodynamics and cortisol levels.

\section{MATERIALS AND METHODS}

\section{Patient Population and Study Design}

This study is a prospective, randomized, clinical trial approved by the Istanbul University Cerrapasa Medical Faculty Ethics Committee. Informed consent was obtained from the families of the patients. Age, gender, height, weight, co-morbidity, diagnosis, and Glasgow come score values of all patients were recorded. "Acute Physiology and Chronic Health Evaluation II" (APACHE II) scores were evaluated from clinical data available after the first 24 hours of intensive care.

Patients excluded from the study were those with a medical history of steroid therapy (obtained from their family) before RSI, those younger than 18 years of age, those who were pregnant, those with an endocrine disease and sepsis and those who had cardiopulmonary arrest before arrival in hospital. For all patients who received emergency surgical department (all patients diagnosis were acute abdomen), an approximate $30 \mathrm{ml} / \mathrm{kg}$ IV bolus Isolyte S (Eczacıbaşı-Baxter, Turkey) was infused following the first hemodynamic measurements. Those with systolic arterial pressures lower than $90 \mathrm{mmHg}$ were given $250 \mathrm{ml}$ of $6 \%$ Hydroxyethyl (HES) 130/0.4 (Voluven, Fresenius Kabi, Germany). A target of 0.5 $\mathrm{ml} / \mathrm{kg} / \mathrm{h}$ was established for urinary output according to the early goal-directed therapy protocol. Patients who were not able to reach those targets and those who were in need of inotropic support prior to intubation (RSI) were excluded from the study.

Sixty patients were randomly divided into three groups $(n=20)$. Randomization was achieved by computer.

\section{Data Collection}

Following randomization, and before intubation in the emergency department, blood samples were taken for cortisol measurements, and hemodynamic parameters (systolic-diastolic arterial pressure, mean arterial pressure, heart rate, SOFA score) were recorded.

Group I patients were intubated with a $0.3 \mathrm{mg} / \mathrm{kg}$ etomidate IV (Etomidate Lipuro, Braun, Germany) and a $1.2 \mathrm{mg} / \mathrm{kg}$ rocuronium IV (Esmeron, Organon, Belgium).
Group II patients were intubated with a $0.3 \mathrm{mg} / \mathrm{kg}$ etomidate IV and rocuronium I.2 mg/kg IV following a $2 \mathrm{mg} / \mathrm{kg}$ methylprednisolone IV (Prednol, Mustafa Nevzat, Turkey) given 2-4 minutes before etomidate.

Group III patients were intubated with a $0.15 \mathrm{mg} / \mathrm{kg}$ midazolam $^{[7]}$ IV (Dormicum, Roche, France) and $1.2 \mathrm{mg} / \mathrm{kg}$ rocuronium IV.

Figure $\mathrm{I}$ is a flow diagram of all patients intubated during the study period.

The measurements (plasma cortisol level, systolic-diastolicmean blood pressures, heart rates, and SOFA score) were repeated at hours 4 and 24 of the study.

\section{Cortisol Measurement Technique}

Plasma cortisol measurements were taken by competitive immunoassay with the use of an electrochemiluminescence immunoassay (ECLIA: Roche, Mannheim, Germany). After the blood sample was centrifuged, using paramagnetic particle in the supernatant liquid and antibody bonding, antigens were removed by magnet and cortisol was measured in $\mu \mathrm{g} / \mathrm{dl}$ with four different emissions.

\section{Statistical Analysis}

Data were expressed as the mean \pm standard deviation (SD). Sample sizes of 20,20 and 20 were obtained from the three groups whose mean values were to be compared. The total sample of 60 subjects achieved $95 \%$ power to detect a difference of at least 10.00 using the "Tukey-Kramer" (Pairwise) multiple comparison test at a 0.05 significance level. Differences between groups were considered significant at $p<0.05$. When comparing the three groups, "one way ANOVA" was used for parameters showing normal distribution, and "Tukey HSD” was used as post-hoc test. When comparing numerical parameters showing abnormal distribution between groups, "Mann-Whitney U" test was used. In repetitive parameters showing normal distribution, "Variance Analysis" test was used, and in repetitive parameters showing non-normal distribution, "Friedman Variance Analysis" was used. In the comparison of categorical variables, crosstab statistics were used.

\section{RESULTS}

No significant difference was observed between the demographic data (Table I).

In within-group comparison, although systolic arterial pressure values decreased in Groups I and II at the $4^{\text {th }}$ hour, only the decrease in Group I was statistically significant $(p=0.032)$. Systolic arterial pressure values decreased in all three groups by hour 24 compared to preinduction values (In Group I $p=0.003$, in Group II $p=0.04 I$ and in III $p=0.038)$ (Table 2). 


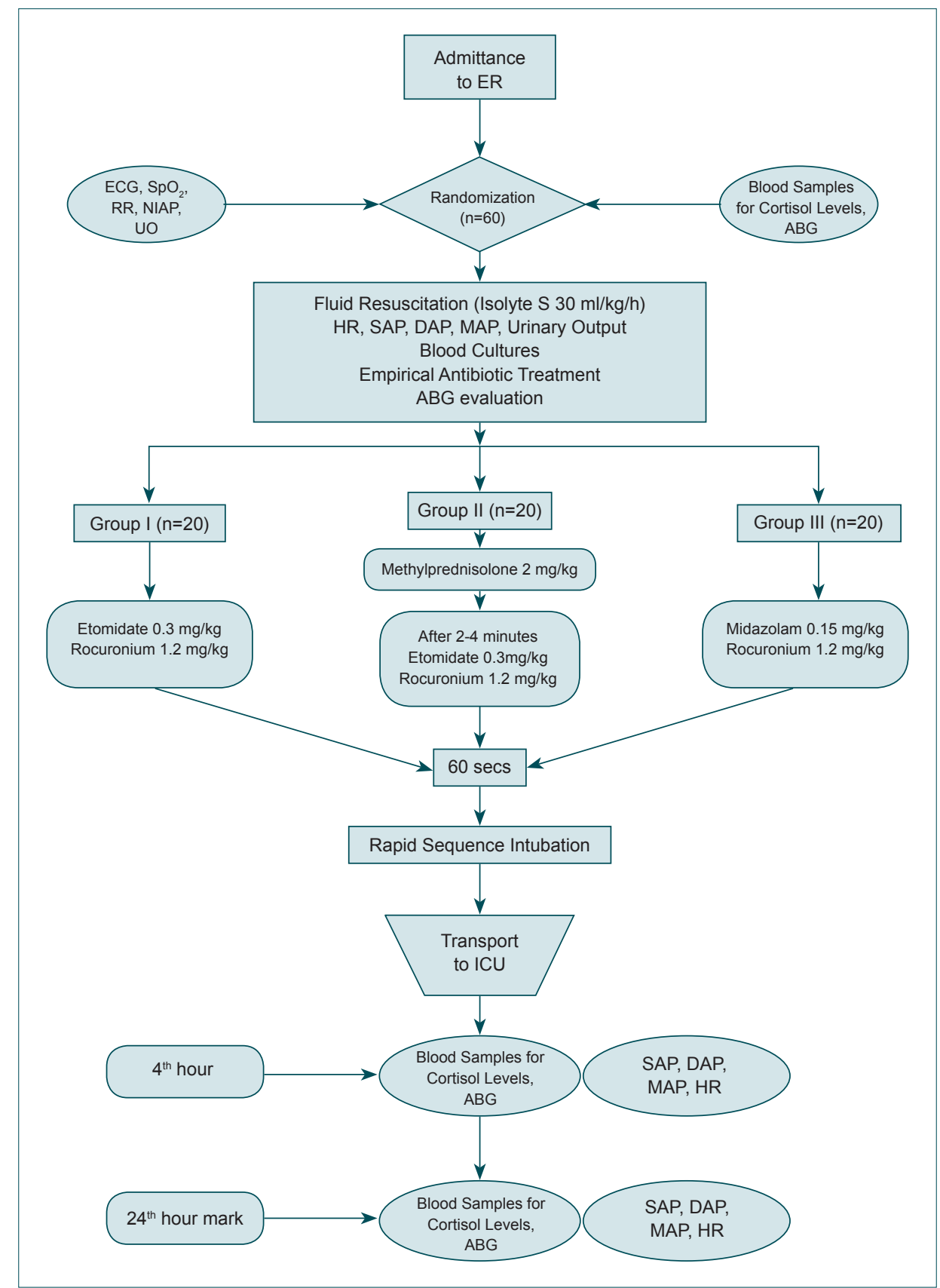

Figure 1. A flow diagram of all patients intubated during the study period. ER: Emergency room; ECG: Echocardiography; RR: Respiratory rate; $\mathrm{SpO}_{2}$ : Peripheral oxygen saturation; NIAP: Noninvasive arterial pressure; HR: Heart rate; SAP: Systolic arterial pressure; DAP: Diastolic arterial pressure; MAP: Mean arterial pressure; ICU: Intensive care unit; ABG: Arterial blood gas.

In between group comparison, systolic arterial pressure values were significantly lower at the $4^{\text {th }}$ hour in Group I compared to Groups II $(p=0.042)$ and III $(p=0.009)$ and at the $24^{\text {th }}$ hour in Group I compared to Groups II $(p=0.033)$ and III $(p=0.021)$. No significant difference was observed between Groups II and III (Table 2).

In within-group comparison, $4^{\text {th }}$ and $24^{\text {th }}$ hour diastolic arterial pressure values of only Group I were significant compared to preinduction values $(p=0.038$ and $p=0.031$ respectively) (Table 2$)$.
In between-group comparison, diastolic arterial pressure values were significantly lower at 24 hours in Group I compared with Groups II and III ( $p=0.040$ and $p=0.027$ respectively). No significant difference was observed between Groups II and III (Table 2).

In within-group comparison, a decrease in mean arterial pressure values at the $4^{\text {th }}$ hour was observed in Group I compared to initial values $(p=0.046)$ (Table 3$)$. No difference was observed in the other groups. At 24 hours, a decrease was 
Table I. Demographic data of the patients

\begin{tabular}{lccr}
\hline & Group I $(\mathbf{n = 2 0})$ & Group II $(\mathbf{n = 2 0 )}$ & Group III $(\mathbf{n = 2 0})$ \\
\hline Gender (Female/Male) & $9 / I I$ & $11 / 9$ & $8 / 12$ \\
Ages (year) & $58.4 \pm 18.4$ & $55.0 \pm 18.3$ & $52.3 \pm 20.4$ \\
Weight (kg) & $61.0 \pm 20.0$ & $63.0 \pm 21.0$ & $66.0 \pm 22.0$ \\
APACHE II & $18.0 \pm 8.0$ & $17.0 \pm 6.0$ & $19.0 \pm 6.0$ \\
\hline
\end{tabular}

Apache II: Acute Physiology and Chronic Health Evaluation II.

Table 2. Systolic and diastolic arterial pressure values of the patients (Mean \pm SD)

\begin{tabular}{|c|c|c|c|c|}
\hline & Group I & Group II & Group III & p (between groups) \\
\hline \multirow[t]{3}{*}{ SAP Preinduction $(\mathrm{mmHg})$} & $129.3 \pm 23.9$ & $126.4 \pm 28.7$ & $128.3 \pm 21.2$ & Group I-II, $p=0.173$ \\
\hline & & & & Group I-III, $p=0.57 \mathrm{I}$ \\
\hline & & & & Group II-III, $p=0.652$ \\
\hline \multirow[t]{3}{*}{ SAP $4^{\text {th }}$ hour $(\mathrm{mmHg})$} & $115.7 \pm 29.6^{*}$ & $122.5 \pm 26.6^{\dagger}$ & $130.5 \pm 21.2^{\ddagger \ddagger}$ & Group I-II, $p=0.042$ \\
\hline & & & & Group I-III, p=0.009 \\
\hline & & & & Group II-III, $p=0.112$ \\
\hline \multirow[t]{3}{*}{ SAP $24^{\text {th }}$ hour $(\mathrm{mmHg})$} & $96.4 \pm 25.0^{* * *}$ & $1 \mid 6.3 \pm 21.7^{* \dagger}$ & $118.2 \pm 20.2^{* \ddagger}$ & Grup I-II, $p=0.033$ \\
\hline & & & & Grup I-III, $p=0.002$ \\
\hline & & & & Group II-III, $p=0.421$ \\
\hline \multirow[t]{3}{*}{$\mathrm{P}$ (within group comparison) } & Pre- $-{ }^{4 t h}, p=0.032$ & Pre $-4^{\text {th }}, p=0.68 \mathrm{I}$ & Pre $-4^{\text {th }}, p=0.910$ & \\
\hline & Pre- $24^{\text {th }}, p=0.003$ & Pre $-24^{\text {th }}, p=0.04 \mathrm{I}$ & Pre- $24^{\text {th }}, p=0.038$ & \\
\hline & $4^{\text {th }}-24^{\text {th }}, p=0.045$ & $4^{\text {th }}-24^{\text {th }}, p=0.21$ & $4^{\text {th }}-24^{\text {th }}, p=0.052$ & \\
\hline \multirow[t]{3}{*}{ DAP Preinduction $(\mathrm{mmHg})$} & $80.3 \pm 14.1$ & $78.1 \pm 15.2$ & $77.8 \pm 17.2$ & Group I-II, $p=0.567$ \\
\hline & & & & Group I-III, p=0.644 \\
\hline & & & & Group II-III, $p=0.245$ \\
\hline \multirow[t]{3}{*}{ DAP $4^{\text {th }}$ hour $(\mathrm{mmHg})$} & $72.3 \pm 16.4^{*}$ & $72.7 \pm 13.5$ & $74.8 \pm 14.1$ & Group I-II, $p=0.659$ \\
\hline & & & & Group I-III, $p=0.126$ \\
\hline & & & & Group II-III, $p=0.750$ \\
\hline \multirow[t]{3}{*}{ DAP $24^{\text {th }}$ hour $(\mathrm{mmHg})$} & $63.8 \pm 13.8^{*}$ & $72.0 \pm 13.2^{\dagger}$ & $74.7 \pm 11.3^{\ddagger}$ & Grup I-II, $p=0.040$ \\
\hline & & & & Grup I-III, $p=0.027$ \\
\hline & & & & Group II-III, $p=0.342$ \\
\hline \multirow[t]{3}{*}{$\mathrm{P}$ (within group comparison) } & Pre $-4^{\text {th }}, p=0.038$ & Pre $-4^{\text {th }}, p=0.083$ & Pre $-4^{\text {th }}, p=0.552$ & \\
\hline & Pre- $24^{\text {th }}, p=0.031$ & Pre- $24^{\text {th }}, p=0.105$ & Pre- $24^{\text {th }}, p=0.412$ & \\
\hline & $4^{\text {th }}-24^{\text {th }}, p=0.068$ & $4^{\text {th }}-24^{\text {th }}, p=0.864$ & $4^{\text {th }}-24^{\text {th }}, p=0.876$ & \\
\hline
\end{tabular}

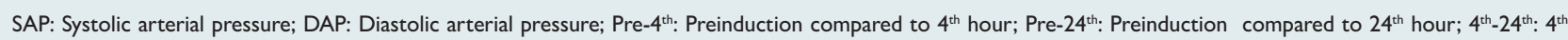
hour compared to $24^{\text {th }}$ hour. ${ }^{*} \mathrm{p}<0.05 ;{ }^{* *} \mathrm{p}<0.01 ;{ }^{* * * *} \mathrm{p}<0.00$ I preinduction vs $4^{\text {th }}$ hours and $24^{\text {th }}$ hours within groups; ${ }^{\dagger} \mathrm{p}<0.05,{ }^{\dagger t} \mathrm{p}<0.0 \mathrm{I}$ Comparison of groups I and II; ${ }^{\ddagger} \mathrm{p}<0.05$; ${ }^{\text {\#† }} \mathrm{p}<0.0$ I comparison of groups I and III.

observed in all three groups in mean arterial pressure values compared to initial values $(p=0.007, p=0.035$, and $p=0.027$, respectively) (Table 3 ).

In between-group comparison, mean arterial pressure values at 4 hours were higher in Groups II and III compared to Group I $(p=0.034$ and $p=0.039$, respectively). Mean arterial pressure values at 24 hours were higher in Groups II and III compared to Group I ( $p=0.009$ and $p=0.006$, respectively). No significant difference was observed between Group II and III (Table 3).

In within-group comparison, heart rate values at 24 hours were significantly higher only in Group I compared to both preinduction and $4^{\text {th }}$ hour heart rate values $(p=0.004$ and $p=0.006$, respectively) (Table 3 ). 
Table 3. Mean arterial pressure and heart rate values of the patients (Mean \pm SD)

\begin{tabular}{|c|c|c|c|c|}
\hline & Group I & Group II & Group III & p (between groups) \\
\hline \multirow[t]{3}{*}{ MAP Preinduction $(\mathrm{mmHg})$} & $97 \pm 22.8$ & $94.0 \pm 21.9$ & $95.0 \pm 22.3$ & Group I-II, $p=0.334$ \\
\hline & & & & Group I-III, $p=0.543$ \\
\hline & & & & Group II-III, $p=0.778$ \\
\hline \multirow[t]{3}{*}{ MAP $4^{\text {th }}$ hour $(\mathrm{mmHg})$} & $89.0 \pm 20.6^{*}$ & $92.0 \pm 19.8^{+}$ & $93 \pm 21.9 \ddagger$ & Group I-II, $p=0.034$ \\
\hline & & & & Group I-III, $p=0.039$ \\
\hline & & & & Group II-III, $p=0.892$ \\
\hline \multirow[t]{3}{*}{ MAP $24^{\text {th }}$ hour $(\mathrm{mmHg})$} & $75 \pm 18.4^{* *}$ & $87 \pm 17.6^{*}+t$ & $89.0 \pm 19.6^{*} \neq \pm$ & Group I-II, $p=0.009$ \\
\hline & & & & Group I-III, $p=0.006$ \\
\hline & & & & Group II-III, $p=0.37$ I \\
\hline \multirow[t]{3}{*}{$\mathrm{P}$ (within group comparison) } & Pre $-4^{\text {th }}, p=0.046$ & Pre $-4^{\text {th }}, p=0.375$ & Pre $-4^{\text {th }}, p=0.790$ & \\
\hline & Pre $-24^{\text {th }}, p=0.007$ & Pre $-24^{\text {th }}, p=0.035$ & Pre $-24^{\text {th }}, p=0.027$ & \\
\hline & $4^{\text {th }}-24^{\text {th }}, p=0.092$ & $4^{\text {th }}-24^{\text {th }}, p=0.589$ & $4^{\text {th }}-24^{\text {th }}, p=0.135$ & \\
\hline \multirow[t]{3}{*}{ HR Preinduction (beat/min) } & $92.1 \pm 18.3$ & $89.8 \pm 18.8$ & $86.6 \pm 15.5$ & Group I-II, $p=0.191$ \\
\hline & & & & Group I-III, $p=0.177$ \\
\hline & & & & Group II-III, $p=0.217$ \\
\hline \multirow[t]{3}{*}{ HR $4^{\text {th }}$ hour (Beat/min) } & $93.3 \pm 18.4$ & $91.4 \pm 20.0^{+1 t}$ & $84.6 \pm 17.3^{\ddagger \ddagger}$ & Group I-II, $p=0.009$ \\
\hline & & & & Group I-III, $p=0.004$ \\
\hline & & & & Group II-III, $p=0.03$ I \\
\hline \multirow[t]{3}{*}{ HR 24 $4^{\text {th }}$ hour (Beat/min) } & $110.0 \pm 19.4^{* *}$ & $97.9 \pm 13.5^{+1}$ & $86.1 \pm 12.6 \neq$ & Group I-II, $p=0.005$ \\
\hline & & & & Group I-III, $p=0.00 \mathrm{I}$ \\
\hline & & & & Group II-III, $p=0.008$ \\
\hline \multirow[t]{3}{*}{$\mathrm{P}$ (within group comparison) } & Pre $-4^{\text {th }}, p=0.212$ & Pre $-4^{\text {th }}, p=0.480$ & Pre $-4^{\text {th }}, p=0.665$ & \\
\hline & Pre $-24^{\text {th }}, p=0.006$ & Pre $-24^{\text {th }}, p=0.08 \mathrm{I}$ & Pre- $24^{\text {th }}, p=0.915$ & \\
\hline & $4^{\text {th }}-24^{\text {th }}, p=0.004$ & $4^{\mathrm{th}}-24^{\mathrm{th}}, p=0.120$ & $4^{\text {th }}-24^{\text {th }}, p=0.601$ & \\
\hline
\end{tabular}

MAP: Mean arterial pressure; HR: Heart rate; Pre- $4^{\text {th }}$ Preinduction compared to $4^{\text {th }}$ hour; Pre- $24^{\text {th: }}$ Preinduction compared to $24^{\text {th }}$ hour; $4^{\text {th }}-24^{\text {th: }} 4^{\text {th }}$ hour compared to

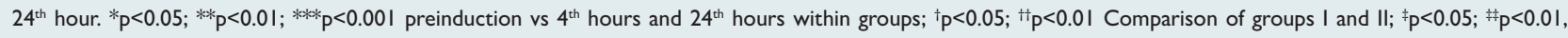
Comparison of groups I and III.

In between-group comparison, heart rate values were significantly lower at the $4^{\text {th }}$ hour in Group I compared to Groups II and III ( $p=0.009$ and $p=0.004)$. Heart rate values were significantly higher at the $24^{\text {th }}$ hour in Group I compared to Groups II and III $(p=0.005$ and $p=0.00$ I). Both at $4^{\text {th }}$ and $24^{\text {th }}$ hours, Group II heart rate values were higher compared to Group III ( $p=0.03$ I and $p=0.008$, respectively) (Table 3).

In within-group comparison, $4^{\text {th }}$ hour SOFA scores of Groups I and III were lower compared to initial values $(p=0.025$ and $p=0.008$, respectively). SOFA scores at 24 hours were lower in all three groups compared to initial values $(p=0.002$, $p=0.009$ and $p=0.004$, respectively) (Table 4).

In between-group comparison, Group III had lower SOFA scores at the $4^{\text {th }}$ hour compared to Groups I and II $(p=0.032$ and $p=0.04 \mathrm{I}$, respectively) and at the $24^{\text {th }}$ hour compared to Groups I and II ( $p=0.039$ and $p=0.023$, respectively) (Table 4).
In within-group comparison, plasma cortisol levels at the $4^{\text {th }}$ hour were lower in all groups compared to preinduction values $(p<0.001, p=0.021, p=0.043$, respectively). Plasma cortisol levels at the $24^{\text {th }}$ hour were lower in Group I compared to initial values $(p=0.013)$. There was an increase in the plasma cortisol levels of Groups II and III at the $24^{\text {th }}$ hour compared to initial values. Only in Group III was this increase statistically significant when compared with the preinduction values $(p=0.008)$. Cortisol levels at the $24^{\text {th }}$ hour were higher compared to the $4^{\text {th }}$ hour cortisol levels in Group I $(p=0.007)$ (Table 4).

In between-group comparison, plasma cortisol levels at the $4^{\text {th }}$ hour were lower in Group I compared to Groups II and III $(p<0.00$ I and $p<0.00$ I, respectively). Plasma cortisol levels at the $24^{\text {th }}$ hour were lower in Group I compared to Groups II and III $(p<0.00 \mathrm{I}$ and $p=0.00 \mathrm{I}$, respectively). There was a significant difference in the $24^{\text {th }}$ hour values between Groups II and III $(p=0.039)$ (Table 4). 
Table 4. SOFA scores and plasma cortisol levels of the patients (Mean \pm SD)

\begin{tabular}{|c|c|c|c|c|}
\hline & Group I & Group II & Group III & p (between groups) \\
\hline \multirow[t]{3}{*}{ SOFA preinduction } & $13 \pm 2.8$ & $11.0 \pm 1.92$ & $10.0 \pm 2.4$ & Group I-II, $p=0.712$ \\
\hline & & & & Group I-III, $p=0.365$ \\
\hline & & & & Group II-III, $p=0.87$ I \\
\hline \multirow[t]{3}{*}{ SOFA $4^{\text {th }}$ hour } & $11.0 \pm 1.6^{*}$ & $10.0 \pm 1.8$ & $8.0 \pm 1.6^{* *+\pi}$ & Group I-II, $p=0.260$ \\
\hline & & & & Group I-III, $p=0.032$ \\
\hline & & & & Group II-III, $p=0.04$ I \\
\hline \multirow[t]{3}{*}{ SOFA $24^{\text {th }}$ hour } & $9.0 \pm 0.8^{* *}$ & $9.0 \pm 0.6^{* *}$ & $7.0 \pm 0.4^{* *+\pi}$ & Group I-II, $p=0.852$ \\
\hline & & & & Group I-III, $p=0.039$ \\
\hline & & & & Group II-III, $p=0.023$ \\
\hline \multirow[t]{3}{*}{$\mathrm{P}$ (within group comparison) } & Pre $-4^{\text {th }}, p=0.025$ & Pre $-4^{\text {th }}, p=0.576$ & Pre $-4^{\text {th }}, p=0.008$ & \\
\hline & Pre $-24^{\text {th }}, p=0.002$ & Pre- $24^{\text {th }}, p=0.01$ & Pre $-24^{\text {th }}, P=0.004$ & \\
\hline & $4^{\text {th }}-24^{\text {th }}, p=0.034$ & $4^{\text {th }}-24^{\text {th }}, p=0.589$ & $4^{\text {th }}-24^{\text {th }}, p=0.154$ & \\
\hline \multirow[t]{3}{*}{ Cortisol preinduction $(\mu \mathrm{g} / \mathrm{dl})$} & $13.7 \pm 5.5$ & $13.2 \pm 4.5$ & $12.6 \pm 4.6$ & Group I-II, $p=0.676$ \\
\hline & & & & Group I-III, $p=0.248$ \\
\hline & & & & Group II-III, $p=0.560$ \\
\hline \multirow[t]{3}{*}{ Cortisol $4^{\text {th }}$ hour $(\mu g / d l)$} & $6.1 \pm 3.1^{* * *}$ & $10.2 \pm 6.4^{*}+t t$ & $10.5 \pm 6.3^{* * \neq \ddagger}$ & Group I-II $p<0.00$ I \\
\hline & & & & Group I-III, $p<0.00$ I \\
\hline & & & & Group II-III, $p=0.76 \mathrm{I}$ \\
\hline \multirow[t]{3}{*}{ Cortisol $24^{\text {th }}$ hour $(\mu g / d l)$} & $9.3 \pm 4.6^{* *}$ & $13.4 \pm 5.7^{t+t}$ & $15.8 \pm 5.0^{* * * \pm \pm \pi}$ & Group I-II, $p<0.00$ I \\
\hline & & & & Group I-III, $p=0.00 \mathrm{I}$ \\
\hline & & & & Group II-III, $p=0.039$ \\
\hline \multirow[t]{3}{*}{$\mathrm{P}$ (within group comparison) } & Pre- $4^{\text {th }}, p<0.001$ & Pre $-4^{\text {th }}, p=0.021$ & Pre $-4^{\text {th }}, p=0.043$ & \\
\hline & Pre $-24^{\text {th }}, p=0.013$ & Pre $-24^{\text {th }}, p=0.65 \mathrm{I}$ & Pre- $-24^{\text {th }}, p=0.008$ & \\
\hline & $4^{\text {th }}-24^{\text {th }}, p=0.007$ & $4^{\text {th }}-24^{\text {th }}, p=0.037$ & $4^{\text {th }}-24^{\text {th }}, p=0.029$ & \\
\hline
\end{tabular}

SOFA: Sequential Organ Failure Assessment score; Pre- $4^{\text {th }}$ : Preinduction compared to $4^{\text {th }}$ hour; Pre- $24^{\text {th }}:$ preinduction compared to $24^{\text {th }}$ hour; $4^{\text {th }}-24^{\text {th }}: 4^{\text {th }}$ hour compared to $24^{\text {th }}$ hour. ${ }^{*} p<0.05 ;{ }^{* *} p<0.01$; ${ }^{* * *} p<0.00$ I preinduction vs $4^{\text {th }}$ hours and $24^{\text {th }}$ hours within groups; ${ }^{\dagger} p<0.05 ;{ }^{\dagger \dagger} p<0.01$ Comparison of groups I and II; ${ }^{\ddagger} p<0.05 ;{ }^{\ddagger} p<0.01$, Comparison of groups I and III; " $\mathrm{p}<0.05$ Comparison of groups II and III.

\section{DISCUSSION}

Etomidate is a hypnotic agent preferred in patients with poor general status as it enables emergency intubation while keeping hemodynamics relatively stable. ${ }^{[9]}$ However, etomidate is also known to cause adrenal suppression because of its inhibition of I I B-hydroxylase, the enzyme that converts IIßdeoxycortisol to cortisol. ${ }^{[1]}$ Studies have documented that decreased cortisol levels occur approximately 30 minutes after a single bolus dose of etomidate, with a suppression duration lasting as long as 24 hours. ${ }^{[1,3,10]}$ Most patients in need of emergency intubation subsequently receive a diagnosis of severe sepsis or septic shock. Therefore, the use of etomidate in emergency intubations should be re-assessed, as there are ongoing studies, evaluating the relative decrease in the cortisol levels in septic patients.

Our aim in this study was to evaluate and compare the effects of three different regimens for RSI on hemodynamics and cortisol levels: regimens being either a single dose of etomidate, or a steroid followed by etomidate, or midazolam alone. The patients included in our study had intubation indications as a result of acute abdomen related acute respiratory failure, meaning they had at least one organ dysfunction. Included were also patients who might have possible sepsis or would have sepsis even though the initial laboratory values did not support it. Cortisol levels are relatively low in sepsis, which can lead to hemodynamic instability. ${ }^{\left[{ }^{\prime \prime}\right]}$ Therefore, especially in patients with septic shock, hydrocortisone use is recommended. ${ }^{[I]}$ There are studies reporting that etomidate has low or even no impact over cortisol levels in septic shock patients already using steroids. ${ }^{[2]}$ These findings suggest that steroid administration prior to etomidate use may prevent its depressant impact over cortisol.

Many authors report that the negative effects of etomidate on the adrenal cortex used during intubation are lower in patients using steroids for septic shock. ${ }^{[13,14]}$ To explore this 
connection, we administered $2 \mathrm{mg} / \mathrm{kg}$ methylprednisolone prior to the use of etomidate in patients scheduled to undergo RSI. We selected methylprednisolone, as hydrocortisone is expensive and difficult to obtain in our country. Methylprednisolone was given in a single bolus dose since we did not use etomidate in repeating doses. The timing of steroid use during etomidate administration, the dosage, and the steroid type can be further discussed and studied. We were only able to administer methylprednisolone 2-4 minutes before etomidate use as the intubation of patients included in our study was under emergency conditions.

The effect of etomidate on cortisol peaks in the first 4 hours. [3] Accordingly, the use of methylprednisolone immediately before administration of etomidate may be justified theoretically. Ray et al. ${ }^{[15]}$ have suggested that existence of issues as vasopressor dependent hypotension and impaired cardiovascular status should also be taken into account besides the possibility of adrenal suppression when using etomidate in the critically ill patients. Jung et al. ${ }^{[13]}$ have suggested for patients in septic shock treated with hydrocortisone that etomidate does not decrease life-threating complications following intubation, but when associated with hydrocortisone it also does not impair outcome. In the above studies, intubation has been achieved with etomidate in patients receiving steroids. Ray et al. ${ }^{[15]}$ and Jung et al. ${ }^{[3]}$ have both reported that etomidate does not cause adrenal insufficiency but also has no positive effect on life expectancy in patients receiving hydrocortisone before etomidate use.

We were not able to find any studies comparing hemodynamic parameters. In our study, although the $4^{\text {th }}$ and $24^{\text {th }}$ hour MAP values were lower in all groups compared to initial values, the decreases were clinically acceptable and did not cause any perfusion abnormality. Nonetheless, minimal change was observed in Group III where midazolam was used as an induction agent, and maximal change was observed in Group I where only etomidate was used. A reasonable explanation for this is the exclusion of patients not responding to fluid resuscitation, as well as those needing vasoactive or inotropic drugs. They were excluded, as we believed inclusion would have carried ethical issues. This is a limitation of our study. When heart rate values were evaluated, the changes in Groups II and III were within acceptable ranges but in Group I, tachycardia occurred at hour 24. We believe the reason Group I MAP values did not decrease under auto-regulation threshold is that tachycardia occurred as compensation.

Though ketamine has been discussed and favored as an alternative hypnotic to etomidate in recent years, ${ }^{[15-17]}$ we chose not to use ketamine in our study because of its consequences in emergency patients with poor general status and fluidelectrolyte imbalances. Furthermore, it is difficult to get sufficient anamnesis from patients who need emergency intubation or from their relatives, which might result in overlooking histories of epilepsy, increased intracranial pressure or severe cardiac problems. The use of ketamine in patients with these histories can cause complications. ${ }^{[17,18]}$ Ketamine also causes an increase in salivation that can lead to laryngospasm and difficulty in the glottic view during RSI. In conclusion, administration of methylprednisolone 2-4 minutes before the use of etomidate can prevent adrenal insufficiency in patients undergoing rapid sequence intubation in emergencies.

More stable hemodynamics were demonstrated in the group that was administered with midazolam and in the group that received methylprednisolone before the use of etomidate.

We were not able to find similar studies where SOFA scores were compared. In our study, even though scores in all groups decreased at the $24^{\text {th }}$ hour, the most evident decrease was in Group III. As all our results confirmed, Group III where midazolam was used, was hemodynamically the most stable and had the highest cortisol levels.

\section{Conclusion}

Firstly, midazolam has a better clinical effect in terms of hemodynamics and cortisol levels and, secondly, methylprednisolone given minutes before etomidate can decrease or even prevent adrenal insufficiency. We opted for midazolam because it is a benzodiazepine that does not cause profound hypotension if used in moderate doses $(0.15 \mathrm{mg} / \mathrm{kg}){ }^{[7]}$ There are various studies reporting hypotension with midazolam. [19-22] We did not encounter any hypotension periods during intubation in the midazolam group. On the contrary, we observed improved hemodynamics compared with the etomidate group. In addition, midazolam can be used in low induction doses as an alternative to etomidate. The difference of our results from other studies may be explained by the difference of demographic data of our patients.

We concluded that the administration of methylprednisolone minutes before the use of etomidate could prevent adrenal insufficiency in patients undergoing rapid sequence intubation in emergency situations. In addition, midazolam can be used in low induction doses as an alternative to etomidate.

Conflict of interest: None declared.

\section{REFERENCES}

1. Schenarts CL, Burton JH, Riker RR. Adrenocortical dysfunction following etomidate induction in emergency department patients. Acad Emerg Med 2001;8:1-7. CrossRef

2. Tekwani KL, Watts HF, Sweis RT, Rzechula KH, Kulstad EB. A comparison of the effects of etomidate and midazolam on hospital length of stay in patients with suspected sepsis: a prospective, randomized study. Ann Emerg Med 2010;56:481-9. CrossRef

3. Vinclair M, Broux C, Faure P, Brun J, Genty C, Jacquot C, et al. Duration of adrenal inhibition following a single dose of etomidate in critically ill patients. Intensive Care Med 2008;34:714-9. CrossRef

4. Fengler BT. Should etomidate be used for rapid-sequence intubation in- 
duction in critically ill septic patients? Am J Emerg Med 2008;26:22932. CrossRef

5. Elliot M, Brown G, Kuo IF. Does etomidate increase vasopressor requirements in patients needing mechanical ventilation? Can J Hosp Pharm 2012;65:272-6. CrossRef

6. Dmello D, Taylor S, O’Brien J, Matuschak GM. Outcomes of etomidate in severe sepsis and septic shock. Chest 2010;138:1327-32. CrossRef

7. Sagarin MJ, Barton ED, Sakles JC, Vissers RJ, Chiang V, Walls RM. Underdosing of midazolam in emergency endotracheal intubation. Acad Emerg Med 2003;10:329-38. CrossRef

8. Hampton JP. Rapid-sequence intubation and the role of the emergency department pharmacist. Am J Health Syst Pharm 2011;68:1320-30.

9. Bergen JM, Smith DC. A review of etomidate for rapid sequence intubation in the emergency department. J Emerg Med 1997;15:221-30. CrossRef

10. Majesko A, Darby JM. Etomidate and adrenal insufficiency: the controversy continues. Crit Care 2010;14:338. CrossRef

11. Keh D, Goodman S, Sprung CL. Corticosteroid therapy in patients with severe sepsis and septic shock. Semin Respir Crit Care Med 2004;25:713-9. CrossRef

12. McPhee LC, Badawi O, Fraser GL, Lerwick PA, Riker RR, Zuckerman $\mathrm{IH}$, et al. Single-dose etomidate is not associated with increased mortality in ICU patients with sepsis: analysis of a large electronic ICU database. Crit Care Med 2013;41:774-83. CrossRef

13. Jung B, Clavieras N, Nougaret S, Molinari N, Roquilly A, Cisse M, et al. Effects of etomidate on complications related to intubation and on mortality in septic shock patients treated with hydrocortisone: a propensity score analysis. Crit Care 2012;16:224. CrossRef
14. Dmello D. Supplemental corticosteroids after intubation using etomidate in severe sepsis and septic shock. Crit Care Med 2012;40:2003-4. CrossRef

15. Ray DC, McKeown DW. Effect of induction agent on vasopressor and steroid use, and outcome in patients with septic shock. Crit Care 2007;11:56. CrossRef

16. Jabre P, Combes X, Lapostolle F, Dhaouadi M, Ricard-Hibon A, Vivien $\mathrm{B}$, et al. Etomidate versus ketamine for rapid sequence intubation in acutely ill patients: a multicentre randomised controlled trial. Lancet 2009;374:293-300. CrossRef

17. Scherzer D, Leder M, Tobias JD. Pro-con debate: etomidate or ketamine for rapid sequence intubation in pediatric patients. J Pediatr Pharmacol Ther 2012;17:142-9. CrossRef

18. Dewhirst E, Frazier WJ, Leder M, Fraser DD, Tobias JD. Cardiac arrest following ketamine administration for rapid sequence intubation.J Intensive Care Med 2013;28:375-9. CrossRef

19. Davis DP, Kimbro TA, Vilke GM. The use of midazolam for prehospital rapid-sequence intubation may be associated with a dose-related increase in hypotension. Prehosp Emerg Care 2001;5:163-8. CrossRef

20. Choi YF, Wong TW, Lau CC. Midazolam is more likely to cause hypotension than etomidate in emergency department rapid sequence intubation. Emerg Med J 2004;21:700-2. CrossRef

21. Jacoby J, Heller M, Nicholas J, Patel N, Cesta M, Smith G, et al. Etomidate versus midazolam for out-of-hospital intubation: a prospective, randomized trial. Ann Emerg Med 2006;47:525-30. CrossRef

22. Swanson ER, Fosnocht DE, Jensen SC. Comparison of etomidate and midazolam for prehospital rapid-sequence intubation. Prehosp Emerg Care 2004;8:273-9. CrossRef

\title{
ORIJJINAL ÇALIŞMA - ÖZET
}

\section{Acil entübasyon sırasında tek doz etomidatın hemodinami ve adrenal korteks üzerine etkisi Dr. Güniz Meyancı Köksal, ${ }^{1}$ Dr. Emre Erbabacan, ${ }^{1}$ Dr. Yusuf Tunalı, ${ }^{1}$ Dr. Gülşah Karaören, ${ }^{1}$ Dr. Suphi Vehid, ${ }^{2}$ Dr. Hüseyin Öz}

\begin{abstract}
${ }^{1}$ İstanbul Üniversitesi Cerrahpaşa Tıp Fakültesi, Anesteziyoloji ve Reanimasyon Anabilim Dalı, İstanbul
${ }^{2}$ İstanbul Üniversitesi Cerrahpaşa Tıp Fakültesi, Biyoistatistik Anabilim Dalı, İstanbul

AMAÇ: Hızı sıralı enbütasyon sırasında tek doz etomidat ve etomidat öncesi kullanılan steroidin hemodinami ve kortizol seviyeleri üzerine etkisini araştırmayı amaçladık.

GEREÇ VE YÖNTEM: Altmış hasta üç grubu ayrıldı $(n=20)$. Entübasyon öncesi ve dördüncü ve 24. saatlerde, kortizol ölçümleri için kan örnekleri alındı, hemodinamik parametreler (sistolik, diyastolik, ortalama arter basıncı, kalp atım hızı) ve SOFA skorları not edildi. Entübasyon, Grup l'de 0.3 $\mathrm{mg} / \mathrm{kg}$ IV etomidat ile, Grup II'de IV $2 \mathrm{mg} / \mathrm{kg}$ metilprednizolonu takiben $0.3 \mathrm{mg} / \mathrm{kg}$ etomidat ile, Grup III'de IV $0.15 \mathrm{mg} / \mathrm{kg}$ midazolam ile sağlandı. BULGULAR: Ortalama arter basıncı değerleri 24. saatte, Grup II ve Grup IIl'e göre Grup l'de daha düşüktü ( $p=0.009$ ve 0.006 ). Grup l'de 24 . saatte kalp atım hızı Grup II ve Grup IIl'e göre yüksekti $(p=0.005$ ve $p=0.00$ I). Kortizol seviyeleri Grup l'de dördüncü $(p<0.00$ I ve $p<0.00$ I) ve 24 . saatlerde $(p<0.00$ I ve $p=0.00$ I) Grup II ve III'e göre daha düşüktü.

TARTIŞMA: Acil şartlarda etomidat kullanımından iki-dört dakika önce uygulanan metilprednizolon hızlı sıralı entübasyon yapılan hastalarda adrenal yetersizliği engelleyebilir. Ayrıca, midazolam düşük indüksiyon dozlarında etomidata alternatif olarak kullanılabilir. Anahtar sözcükler: Adrenal yetersizlik; etomidate; hızlı-sıralı entübasyon; midazolam.
\end{abstract}

Ulus Travma Acil Cerrahi Derg 2015;2I(5):358-365 doi: 10.5505/tjtes.2015.06325 